землями. Наказ Міністра оборони України від 22 грудня 1997 р. № 483. Офічійний веб-портал Верховної Ради Украӥни. URL: https://zakon.rada.gov.ua/rada/show/v0483322-97

16. Про затвердження Порядку відчуження земельних ділянок, на яких розташовані об’єкти нерухомого військового майна, що підлягають реалізації, та земельних ділянок, які вивільняються у процесі реформування Збройних Сил і Державної спеціальної служби транспорту. Постанова Кабінету Міністрів України від 22 травня 2013 р. № 436. Офіиійний вісник України. 2013. № 48. Ст. 1721. (Із змінами).

17. Мірошниченко А. М., Марусенко Р. І. Науково-практичний коментар Земельного кодексу України. К.: Алерта; Центр учбової літератури, 2011. 520 с.

18. Про затвердження переліку видів господарської діяльності, здійснення якої дозволяється військовим частинам: Постанова Кабінету Міністрів України від 25 липня 2000 р. № 1171. Офіціийний вісник України. 2009. № 29. Ст. 973. (Із змінами).

19. Про затвердження Порядку реєстрації військових частин як суб'єктів господарської діяльності у Збройних Силах: Постанова Кабінету Міністрів України від 3 травня 2000 р. № 749. Офіиійний вісник Украӥни. 2000. № 18. Ст. 752. (Із змінами).

20. Про порядок надання дозволу військовим частинам на передачу закріпленого за ними рухомого та не рухомого майна в оренду: Постанова Кабінету Міністрів України від 11 травня 2000 р. № 778. Офіиійний вісник України. 2000. № 20. Ст. 821.

DOI 10.31558/2518-7953.2018.1-2.14

УДК 346.9

А. А. Тварковський

аспірант Донецького національного університету імені Василя Стуса

\title{
ЩОДО ПРАВОВОЇ ОСНОВИ ВІДНОВЛЕННЯ ПЛАТОСПРОМОЖНОСТІ АБО ВИЗНАННЯ БАНКРУТОМ ФІЗИЧНОЇ ОСОБИ-ПІДПРИЕМЦЯ
}

Ключові слова: фізична особа-підприємечь, банкрутство, відновлення платоспроможності, визнання банкрутом, саначія, розпорядження майном, правова основа.

В умовах ринкової економіки діяльність фізичної особи-підприємця несе для неї низку ризиків та може призвести до неплатоспроможності такого суб'єкта господарювання. У свою чергу для відновлення платоспроможності або визнання банкрутом фізичної особи-підприємця важливу роль відіграє відповідна правова основа.

Правову основу банкрутства фізичної особи-підприємця складають Цивільний кодекс України [1], Господарський кодекс України [2], Закон України «Про 
відновлення платоспроможності боржника або визнання його банкрутом» (далі Закон про банкрутство) [3] та інші нормативно-правові акти. При цьому в найближчий час правову основу банкрутства фізичної особи-підприємця визначатиме також Кодекс України з процедур банкрутства, проект якого перебуває на розгляді Верховної Ради України (далі - Проект кодексу) [4].

На сьогодні на законодавчому рівні визначено умови, порядок та підстави відновлення платоспроможності, зокрема, фізичної особи-підприємця або визнання iï банкрутом, застосування ліквідаційної та інших судових й позасудових процедур з метою повного або часткового задоволення вимог кредиторів. Проте низка положень законодавства щодо банкрутства фізичної особи-підприємця потребує удосконалення.

У вітчизняній юридичній науці питання банкрутства досліджували Р. Г. Афанасьєв [5], А. М. Бірюков [6], В. В. Джунь [7], В. А. Малига [8], Б. М. Поляков [9], В. В. Радзивілюк [10], М. І. Тітов [11] та ін. Головна увага вказаних вчених була приділена проблемам вдосконалення законодавства про неспроможність у цілому, проте залишається низка аспектів, пов'язаних із банкрутством фізичної особипідприємця, що потребують подальшого наукового опрацювання.

Вищенаведене вказує на актуальність обраної теми дослідження, метою якого є обтрунтування пропозииій щзодо вдосконалення правової основи відновлення платоспроможності або визнання банкрутом фізичної особи-підприємия.

Загальні положення про відновлення платоспроможності або визнання боржника банкрутом встановлено Цивільним кодексом України, яким передбачено регулювання таких відносин спеціальним законом. При цьому статтею 53 цього Кодексу закріплено, що «фізична особа, яка неспроможна задовольнити вимоги кредиторів, пов'язані із здійсненням нею підприємницької діяльності, може бути визнана банкрутом у порядку, встановленому законом».

Відносин банкрутства фізичної особи-підприємця також стосується глава 23 Господарського кодексу України, якою закріплено ознаки неспроможності суб'єкта підприємницької діяльності; визначено поняття банкрутства; вказано суб'єктів банкрутства, заходи запобігання банкрутству, процедури, що застосовуються до неплатоспроможного боржника, майнові активи неплатоспроможного боржника; визначено коло кредиторів неплатоспроможних боржників; закріплено основні положення щодо здійснення державної політики з питань банкрутства, а також щодо відповідальності за порушення законодавства про банкрутство.

Основним законом, який регулює відносини у сфері відновлення платоспроможності та визнання банкрутом фізичної особи-підприємця, є Закон про банкрутство. Цим Законом визначено: правовий статус Державного органу з питань банкрутства; заходи щодо запобігання банкрутству боржника; судові процедури, які застосовуються до боржника; підвідомчість, підсудність, підстави та наслід- 
ки порушення провадження у справі про банкрутство; порядок провадження у справах про банкрутство; порядок продажу майна у провадженні справи про банкрутство; особливості банкрутства певних категорій боржників; правовий статус арбітражного керуючого; процедури банкрутства, пов'язані з іноземною процедурою банкрутства, а також правові наслідки визнання боржника банкрутом.

Поряд із названими загальними положеннями цей Закон містить і спеціальні положення стосовно банкрутства фізичних осіб-підприємців. Так, статтею 90 Закону про банкрутство закріплено: підстави визнання фізичної особи-підприємця банкрутом; коло суб'єктів ініціювання справи про банкрутство фізичної особипідприємця; неможливість подання заяви про порушення справи про банкрутство кредиторами, вимоги яких пов'язані з зобов'язаннями, що виникли внаслідок заподіяння шкоди життю та здоров'ю громадян, кредиторами, які мають вимоги щодо стягнення аліментів, а також інші вимоги особистого характеру; право боржника під час ініціювання провадження у справі про банкрутство подати та виконати план погашення боргів, вимоги до змісту такого плану; право господарського суду на зміну плану погашення боргів; право господарського суду виключити зі складу ліквідаційної маси майно фізичної особи, на яке згідно з цивільним процесуальним законодавством може бути звернено стягнення, якщо майно є неліквідним чи дохід від реалізації якого істотно не вплине на задоволення вимог кредиторів.

Стаття 91 Закону про банкрутство визначає: порядок розгляду судом справи про банкрутство фізичної особи-підприємця; повноваження господарського суду накласти арешт на майно фізичної особи, за винятком майна, на яке згідно із законодавством України не може бути звернено стягнення, та майна, що перебуває в заставі з підстав, не пов'язаних із здійсненням такою особою підприємницької діяльності; підстави зупинення та відкладення розгляду справи про банкрутство; право на укладення сторонами мирової угоди, а також повноваження господарського суду визнати боржника банкрутом та відкрити ліквідаційну процедуру.

Окрім того, стаття 92 названого Закону передбачає особливості задоволення вимог кредиторів фізичної особи, визнаної банкрутом; відмінний від загального порядок черговості задоволення вимог кредиторів; обмеження для фізичної особи, визнаної банкрутом, протягом трьох років бути зареєстрованою як фізична особа-підприємець; обмеження на придбання майна або грошових коштів у кредит, а також на укладення договорів поруки та на передачу майна у заставу. При цьому названа стаття Закону про банкрутство забороняє відкривати провадження у справі про банкрутство за заявою фізичної особи, визнаної банкрутом, протягом п'яти років.

Разом із тим проведений аналіз статей 90-92 Закону про банкрутство вказує на неоднозначне врегулювання питання про можливість застосування в провадженні у справі про банкрутство фізичної особи-підприємця таких судових процедур 
як розпорядження майном і судова санація. Така неоднозначність у свою чергу $є$ причиною неоднакової судової практики, зокрема, про це свідчать судові акти у господарських справах № 921/295/18, № 902/1706/13, № 902/177/13-г [12, 13, 14].

До кола питань, які також потребують вирішення на рівні Закону про банкрутство, належить питання щодо підстав відкриття провадження у справі про банкрутство фізичних осіб-підприємців, оскільки загальні підстави, передбачені статтею 10 цього Закону, не враховують певних особливостей цих суб'єктів господарювання. Так, у порівнянні з юридичними особами фізичні особи-підприємці можуть відрізнятися кількістю працюючих, обсягами та результатами виробництва, майновими активами і у своїй переважній більшості є суб'єктами малого підприємництва.

Отже, норми Закону про банкрутство щодо відкриття провадження та застосування певних судових процедур у справах про банкрутство фізичних осіб-підприємців потребують доопрацювання за цими напрямами.

При аналізі правової основи відновлення платоспроможності або визнання банкрутом фізичної особи-підприємця доцільно також розглянути проект Кодексу України з процедур банкрутства, адже після прийняття та набрання чинності відповідний законодавчий акт становитиме правову основу та визначатиме особливості розгляду справ про неплатоспроможність фізичних осіб-підприємців.

До загальних положень Проекту кодексу, які застосовуватимуться до усіх боржників, у тому числі і до фізичної особи-підприємця, належать положення, що визначають: правовий статус Державного органу з питань банкрутства та склад законодавства, яке регулює провадження у справах про банкрутство; судові та позасудові процедури, які застосовуються до боржника; порядок розгляду спорів, стороною яких є боржник; підсудність та підстави відкриття провадження у справі про банкрутство (Книга I «Загальна частина»); правовий статус арбітражного керуючого та інші питання, пов’язані із його діяльністю (Книга II «Арбітражний керуючий»); порядок продажу майна у справі про банкрутство; порядок провадження у справах про банкрутство, пов'язаних з іноземною процедурою неплатоспроможності (Книга III «Банкрутство юридичних осіб»).

Крім того, питань банкрутства фізичної особи-підприємця стосуються положення Книги IV «Відновлення платоспроможності фізичної особи» Проекту кодексу, де визначено особливості провадження у справах про неплатоспроможність боржника - фізичної особи. Зокрема, у цій частині Проекту кодексу визначено: юрисдикцію, підсудність, підстави та наслідки відкриття провадження у справі про неплатоспроможність; застосування судових процедур реструктуризації боргів та ліквідації; порядок задоволення вимог кредиторів; правові наслідки закриття провадження про банкрутство фізичної особи; порядок провадження у справах про неплатоспроможність окремих категорій фізичних осіб. У назва- 
них положеннях вказаної Книги IV Проекту кодексу фізична особа-підприємець розглядається як окрема категорія фізичної особи.

Водночас стаття 137 Проекту кодексу крім вищезазначеного також визначає особливості розгляду справ про неплатоспроможність фізичних осіб-підприємців. Так, названою статтею закріплено, що відкриття та закриття провадження у справі про неплатоспроможність фізичної особи-підприємця зумовлює внесення відповідного запису до Єдиного державного реєстру юридичних осіб, фізичних осібпідприємців та громадських формувань. При цьому положення цієї статті передбачають надсилання державному реєстратору ухвали про закриття провадження у справі про неплатоспроможність фізичної особи-підприємця для внесення відповідного запису.

Порівняльний аналіз чинного Закону про банкрутство та Проекту кодексу дає підстави для висновку про те, що їхні норми щодо відновлення платоспроможності або визнання банкрутом фізичної-особи підприємця певним чином відрізняються.

На відміну від Закону про банкрутство норми Проекту кодексу однозначно встановлюють судові процедури, які можуть бути застосовані до боржника фізичної особи-підприємця, проте серед них відсутні такі процедури як розпорядження майном та судова санація. Зокрема, визначено, що до цього боржника застосовуються лише такі судові процедури неплатоспроможності: реструктуризація боргів боржника; погашення боргів боржника.

На перший погляд така правова конструкція норм Проекту кодексу має позитивне значення, оскільки сприятиме їх однозначному тлумаченню у правозастосовній діяльності та ймовірно усуне різну судову практику. Разом із тим, аналізуючи такі положення Проекту кодексу, не можна однозначно стверджувати, що позбавлення господарського суду права застосовувати у справі про банкрутство фізичної особи-підприємця судової процедури розпорядження майном матиме позитивні наслідки для відновлення платоспроможності або визнання банкрутом боржника - фізичної особи-підприємця. Так, на сьогодні господарські суди у деяких випадках застосовують до фізичних осіб-підприємців названі судові процедури як такі, що ефективно сприяють відновленню платоспроможності, з огляду на що залишається відкритим питання про доцільність застосування названих процедур і їх відповідного нормативного закріплення.

Також зміст названих документів відрізняється в частині закріплення підстав відкриття провадження у справі про банкрутство фізичної особи-підприємця. Так, Проект кодексу у порівнянні із чинним Законом, який визначає спільні підстави відкриття провадження у справі про банкрутство для усіх боржників, передбачає особливі підстави для відкриття провадження у справі про банкрутство фізичної особи, які при цьому підлягають застосуванню і для фізичної особи-під- 
приємця. Зокрема, «боржник має право звернутись до господарського суду з заявою про відкриття провадження у справі про неплатоспроможність у разі, якщо:

1) розмір прострочених зобов’язань боржника перед кредитором (кредиторами) становить не менше тридцяти мінімальних розмірів заробітної плати;

2) боржник припинив погашати кредити чи здійснювати інші планові платежі у розмірі більше як п’ятдесят відсотків місячних платежів по кожному з кредитних та інших зобов'язань упродовж двох місяців;

3) винесено постанову у виконавчому провадженні про відсутність у фізичної особи майна, на яке можна звернути стягнення;

4) існують інші обставини, які підтверджують про те, що у найближчий час боржник не зможе виконати грошові зобов'язання чи здійснювати звичайні поточні платежі (загроза неплатоспроможності)» (ст. 115 Проекту кодексу).

При цьому також на відміну від Закону про банкрутство за правилами Проекту кодексу можливість ініціювати порушення провадження у справі про неплатоспроможність надано лише особисто фізичній особі-підприємцю.

Утім судова практика свідчить, що значна кількість справ, які розглядаються на підставі чинного Закону про банкрутство, порушується саме 3 ініціативи кредиторів. Відтак набуває актуальності питання про можливість задоволення вимог кредиторів у випадку, коли боржник у цьому не заінтересований. 3 урахуванням цього, зазначені положення потребують уточнення.

Окрім того, встановлюючи спеціальні підстави для відкриття провадження у справі про банкрутство фізичної особи, Проект кодексу не конкретизує їх саме для фізичної-особи підприємця, хоча як суб'єкт господарювання така особа має значні відмінності як від юридичної особи, так і від звичайної фізичної особи, що має бути враховано законодавцем.

Таким чином, проведений аналіз чинного та перспективного законодавства вказує на наявність низки положень, якими передбачено врегулювання відновлення платоспроможності фізичної особи-підприємця, проте існує ряд норм, які потребують удосконалення. Зокрема, чинний Закон про банкрутство потребує певної конкретизації щодо судових процедур та доповнень стосовно спеціальних підстав для відкриття провадження у справах про банкрутство фізичної особипідприємця, що підтверджує судова практика. Проект кодексу названі питання вирішує не в повній мірі.

3 огляду на вищевикладене, можна запропонувати такі основні напрями удосконалення правової основи відновлення платоспроможності або визнання банкрутом фізичної особи-підприємия:

врегулювання питання застосування у провадженні в справах про банкрутство фізичних осіб-підприємиів судових процедур розпорядження майном та санації, з уточненням підстав та умов їх застосування; 
уточнення положень щзодо можливості порушення справи про банкрутство фізичної особи-підприємия також з ініціативи кредиторів;

конкретизачія підстав щзодо відкриття провадження у справах про банкрутство фізичних осіб-підприємщів як окремих суб 'єктів господарювання.

Для реалізації зазначених напрямів доцільно внести відповідні зміни та доповнення до Кодексу Украӥни з процедур банкрутства після набуття ним чинності.

Подальші дослідження цієї теми доцільно присвятити конкретизації зазначених напрямів удосконалення законодавства щодо відновлення платоспроможності або визнання банкрутом фізичної особи-підприємця.

1. Цивільний кодекс України: Закон України від 16 січня 2003 р. № 435-IV. Вiдомості Верховної Ради України. 2003. № 40. Ст. 356. (Із змінами).

2. Господарський кодекс України: Закон України від 16 січня 2003 р. № 436-IV. Відомості Верховної Ради Украӥни. 2003. № № 18-22. Ст. 144. (Із змінами).

3. Про відновлення платоспроможності боржника або визнання його банкрутом: Закон України від 14 травня 1992 р. № 2343-XII. Відомості Верховної Ради України. 1992. № 31. Ст. 440. (Із змінами).

4. Проект Кодексу України з процедур банкрутства (реєстр. № 8060 від 26 лютого 2018 р). Офіиійний веб-портал Верховної Ради України. URL: http://w1.c1.rada.gov.ua/pls/zweb2/webproc4_1?pf3511=63518 (дата звернення: 15.10.2018).

5. Афанасьев Р. Г. Проблеми правового регулювання банкрутства за законодавством України: дис. ... канд. юрид. наук: 12.00 .04 «Господарське право, господарське процесуальне право». Інститут економіко-правових досліджень. Донецьк, 2001. 189 с.

6. Бірюков О. Н. Інститут неспроможності: порівняльно-правовий аналіз: монографія. Київ: Видавничий центр «Київський університет», 2000. 163 с.

7. Джунь В. В. Інститут неспроможності: світовий досвід розвитку і особливості становлення в Україні: монографія. Львів: Інститут технологій бізнесу і права, 2000. 180 с.

8. Малыга В. А. Правовое обеспечение санации и минимизации негативных последствий банкротства: дис. ... канд. юрид. наук: 12.00 .04 «Господарське право, господарське процесуальне право». НАН Украины, Ин-т экон.-прав. исслед. Донецк, 1999. 191 с.

9. Поляков Б. М. Правові проблеми регулювання неспроможності (банкрутства): дис. ... д-ра юрид. наук: 12.00 .04 «Господарське право, господарське процесуальне право». Інститут держави і права імені В. Корецького. Київ, 2003. 437 с.

10. Радзивілюк В. В. Санація як судова процедура банкрутства: порівняльно-правове дослідження: автореф. дис. ... канд. юрид. наук: 12.00 .04 «Господарське право, господарське процесуальне право». Київський нац. ун-т ім. Тараса Шевченка. Київ, 2000. 17 с.

11. Тітов М. І. Банкрутство: матеріально-правові та процесуальні аспекти. За наук. ред. В. М. Гайворонського. Харків: Фірма «Консум», 1997. 192 с.

12. Ухвала Господарського суду Тернопільської області від 27 серпня 2018 р. у справі № 921/295/18. Єдиний державний реєстр судових рімень. URL: http://reyestr.court.gov.ua/Review/76155298 (дата звернення: 15.10.2018). 
13. Ухвала Господарського суду Вінницької області від 10 січня 2014 р. у справі № 902/1706/13. Сдиний державний реєстр судових рімень. URL: http://reyestr.court.gov.ua/Review/36655363 (дата звернення: 15.10.2018).

14. Ухвала Господарського суду Вінницької області від 4 березня 2014 р. у справі № 902/177/13-г. Сдиний держсавний реєстр судових рішень. URL: http://www.reyestr.court.gov.ua/ Review/37507987 (дата звернення: 15.10.2018).

DOI 10.31558/2518-7953.2018.1-2.15

УДК 346.21

\section{T. М. Немета}

аспірантка Донецького національного університету імені Василя Стуса

\section{ПРАВОВА ОСНОВА ПЕРЕХОДУ ЧАСТКИ УЧАСНИКА У СТАТУТНОМУ КАПІТАЛІ ТОВАРИСТВ З ОБМЕЖЕНОЮ ТА ДОДАТКОВОЮ ВІДПОВІДАЛЬНІСТЮ}

Ключові слова: перехід частки, відчуження частки, статутний капітал, товариства з обмеженою та додатковою відповідальністю, переважне право.

Питання, пов'язані з майновою базою суб'єктів господарювання (джерела формування, зміна і т. п.), в різні часи викликали інтерес багатьох дослідників. Але сутність поняття «перехід частки у статутному капіталі господарського товариства» як правової категорії в науці господарського права дотепер ретельно не досліджувалась. Частіше в юридичній літературі обговорюється розуміння сутності частки, іï правова природа, співвідношення поняття «частка у статутному капіталі товариства» 3 такими поняттями як «корпоративні права», «майнові права» $[1-5]$.

Питання щодо того, що є предметом переходу - частка або права, є дискусійним в науковій літературі. Зокрема, І. В. Спасибо-Фатєєва характеризуючи спори щодо переходу прав на частку у статутному капіталі, називає в їх числі спори щодо відчуження частки у статутному капіталі, виходу учасника, його виключення, щодо переходу частки до спадкоємця або правонаступника учасника товариства (наприклад, при реорганізації) тощо [6, с. 208-254]. В той же час дослідниця акцентує увагу на тому, що в договорах поширено вказувати в якості предмету як частку, так і корпоративні права [6, с. 209]. Наполягаючи на помилковості цієї практики, I. В. Спасибо-Фатєєва зазначає, що позначення як предмету договору корпоративних прав є неправильним у зв'язку з тим, що, по-перше, об'єктом 